\title{
STRATEGIC COMMUNICATION DALAM MEMPERTAHANKAN EKSISTENSI ARSIP UGM SEBAGAI PILOT PROJECT LEMBAGA KEARSIPAN PERGURUAN TINGGI DI INDONESIA
}

\author{
Musliichah \\ Kantor Arsip Universitas Gadjah Mada \\ musliichah@ugm.ac.id
}

\begin{abstract}
Arsip UGM is one of university archives in Indonesia that established on 2004. Arsip UGM is pilot project of university archives in Indonesia. On the first periode, much activities must be done by Arsip UGM to save Arsip UGM reputation. One of the important part to save organization reputation is communication. This article want to riset what is strategic communication that Arsip UGM done on first periode to save the Arsip UGM reputation in UGM and national. On first periode, Arsip UGM has develop publicity archives as communication program. Publicity archives as strategic communication to save Arsip UGM reputation.
\end{abstract}

Keywords: Corporate Communication, strategic communication, publicity archives.

\section{Intisari}

Arsip UGM adalah salah satu lembaga kearsipan perguruan tinggi di Indonesia yang didirikan pada tahun 2004. Arsip UGM menjadi pilot project LKPT di Indonesia. Pada periode awal berdirinya Arsip UGM bayak hal yang harus dilakukan untuk menjaga eksistensi Arsip UGM. Salah satu unsur penting dalam menjaga eksistensi sebuah organisasi adalah komunikasi. Penelitian ini ingin mengkaji komunikasi strategis apa yang dilakukan oleh Arsip UGM pada periode awal supaya lembaga tersebut tetap eksis di tingkat internal UGM maupun di lingkup Indonesia. Hasil penelitian menunjukkan bahwa Arsip UGM sejak awal telah mengembangkan sebuah program terkait komunikasi di bidang kearsipan yaitu publikasi kearsipan. Publikasi kearsipan menjadi komunikasi strategis Arsip UGM dalam menjaga eksistensinya.

Kata kunci: Komunikasi korporat, komunikasi strategis, publikasi kearsipan. 


\section{PENDAHULUAN}

\section{Latar Belakang Masalah}

Tahun 2015 telah dicanangkan sebagai masyarakat informasi. Masyarakat informasi akan melahirkan masyarakat yang mandiri dan aktif dalam pembangunan. Peran bidang komunikasi sangat penting dalam mewujudkan masyarakat informasi. Namun demikian, analisa tentang keberhasilan komunikasi tidak akan mencapai sesuatu apabila dunia informasi sendiri tidak dianalisa. Dalam konteks komunikasi, informasi diposisikan sebagai komoditi. Artinya informasi dapat dikelola sebagai suatu komoditi atau modal. Supaya komoditi tersebut dapat didistribusikan secara luas maka perlu memperhatikan unsur pengadaannya (=acquisition) dan distribusinya. Oleh karena itu perlu diperhatikan juga unsur resource exchange-nya. Supaya sasaran tercapai maka perlu dibangun suatu infrastruktur komunikasi. (Astrid Susanto, 1977:6

Untuk mewujudkan masyarakat informasi pemerintah menerbitkan Undang-Undang Nomor 14 Tahun 2008 tentang Keterbukaan Informasi Publik yang mengatur tentang hak-hak untuk mendapatkan informasi bagi publik. Selanjutnya yang tidak kalah penting untuk diperhatikan adalah informasi itu sendiri atau sumber informasi yang dapat diakses oleh publik. Salah satu sumber informasi yang akurat dan dapat dipertanggungjawabkan adalah arsip. Arsip adalah rekaman informasi dalam berbagai media/ bentuk sesuai dengan perkembangan teknologi yang tercipta dalam konteks penyelenggaraan kehidupan kebangsaan. Menyadari pentingnya sumber informasi maka pemerintah Indonesia pada tahun 2009 menerbitkan Undang-Undang Nomor 43 Tahun 2009 tentang Kearsipan yang mengatur tentang cara penciptaan, pemeliharaan, penggunaan, dan penyusutan arsip beserta bentuk dan kewenangan lembaga kearsipan yang bertanggungjawab atas kegiatan kearsipan tersebut. Lembaga kearsipan menurut UU 43 Tahun 2009 meliputi lembaga kearsipan nasional, lembaga kearsipan propinsi, lembaga kearsipan kabupaten/kota, dan lembaga kearsipan perguruan tinggi.

Gagasan tentang lembaga kearsipan perguruan tinggi telah digulirkan sejak tahun 2001. Arsip Nasional Republik Indonesia telah melakukan serangkaian uji coba untuk perintisan pendirian lembaga kearsipan perguruan tinggi di lima perguruan tinggi yaitu UGM, UI, UNDIP, UNPAD, dan IPB, namun hanya UGM yang berhasil. Tanggal 11 September 2004 didirikan Arsip Universitas Gadjah Mada (Arsip UGM) sebagai lembaga kearsipan perguruan tinggi di UGM. Setelah uji coba tersebut berhasil maka konsep lembaga kearsipan perguruan tinggi/ arsip universitas resmi menjadi lembaga kearsipan di Indonesia dengan dicantumkan dalam UU RI 43/ 2009. Sebagai lembaga kearsipan perguruan tinggi pertama di Indonesia sekaligus pilot project, Arsip UGM menjadi pusat rujukan bagi perguruan tinggi negeri lainnya di Indonesia untuk mendirikan dan mengembangkan arsip universitas. Pendirian dan pengembangan arsip universitas di Indonesia masih rendah. Tentu saja hal ini patut mendapatkan perhatian serius mengingat konsep arsip universitas sangat penting bagi pembangunan bangsa sehingga hal ini diamanatkan dalam undang-undang.

\section{Rumusan Masalah}

Arsip UGM sebagai pilot project dan lembaga kearsipan perguruan tinggi (LKPT) pertama di Indonesia tentu mengalami kendala dan tantangan dalam tumbuh kembang organisasinya, mengingat saat itu konsep LKPT belum populer di Indonesia. Oleh karena itu menarik untuk diteliti bagaimana strategi apa yang dilakukan Arsip UGM dalam upaya mempertahankan dan 
mengembangkan keberadaannya khususnya di bidang komunikasi.

\section{Tujuan}

Penelitian ini dapat memberikan gambaran program komunikasi yang dilakukan oleh Arsip UGM dalam rangka mempertahankan dan mengembangkan institusinya sebagai lembaga kearsipan perguruan tinggi pertama di Indonesia.

\section{Manfaat}

Hasil penelitian ini dapat menjadi referensi atau sumber inspirasi bagi PTN lain yang belum memiliki arsip universitas untuk mendirikan arsip universitas maupun bagi PTN yang sudah memiliki arsip universitas untuk mengembangkan institusinya. Dengan demikian diharapkan dapat mendorong perkembangan arsip perguruan tinggi di Indonesia. Berkembangnya arsip perguruan tinggi di Indonesia dapat mendorong perkembangan ilmu pengetahuan yang akan membawa dampak pada peningkatan kecerdasan dan kesejahteraan Bangsa Indonesia.

\section{Kerangka Pemikiran \\ Komunikasi Organisasi}

Berdasarkan survey terhadap para manajer ketika ditanya masalah yang dihadapi dalam organisasinya, mereka menjawab "komunikasi". Mengapa komunikasi menjadi "momok" yang begitu menakutkan, sehingga sering membuat para manajer dan karyawan frustasi dan kewalahan menghadapinya? Para manajer senior menghabiskan hampir $\quad 80 \%$ waktunya untuk berkomunikasi dengan orang lain baik komunikasi ke samping, ke bawah, dan ke atas di dalam organisasi mereka atau melewati batas-batas organisasi dengan para klien, pelanggan, pembeli, penjual, dan pemerintah. $50 \%$ waktu yang dimiliki seorang manager dihabiskan untuk menurunkan informasi (Ludlow \% Panton, 1996:1-2). Dengan demikian komunikasi yang efektif sangat diperlukan untuk operasional organisasi maupun kehidupan pribadi.

Komunikasi merupakan dasar bagi semua interaksi manusia dan memiliki peranan dominan dalam kehidupan manusia. Fungsi komunikasi bagi individu antara lain mencapai pengertian satu sama lain, membina kepercayaan, mengkoordinir tindakan, merencanakan strategi, melakukan pembagian pekerjaan, melakukan aktivitas kelompok, dan berbagi rasa. Keberhasilan sebuah organisasi sangat ditentukan oleh keberhasilan komunikasi organisasi. Menurut Reed H. Blake dan Edwin O. dalam Rosmawanty (2010:100) komunikasi organisasi merupakan bentuk komunikasi antarpribadi tetapi bersifat khas. Komunikasi ini terjadi dalam batas-batas yang jelas dan berkenaan dengan pencapaian tujuan organisasi.

Menurut Griffin (2012:186), komunikasi dalam sebuah organisasi dapat terjadi dengan berbagai model yang menggambarkan hubungan komunikasi dan aliran informasi. Model tersebut adalah one-up communication untuk fungsi control biasanya berupa instruct, order, interrupt, contradict, change topics; One-down communication; dan one-cross communication. Modelmodel komunikasi ini dapat digunakan untuk melihat bentuk-bentuk komunikasi yang terjadi dalam sebuah organisasi dari sisi kedudukan antara komunikator dan komunikan karena dalam sebuah organisasi hubungan kerja yang dibangun dengan komunikasi merupakan hubungan birokratis yang dibangun berdasarkan hierarkhi berdasarkan struktur organisasi.

Argenti (2009:27) menyatakan bahwa "communication was called rhetoric, using language to persuade whoever was listening to do something". Definisi ini relevan dengan penerapan komunikasi dalam organisasi dimana komunikasi digunakan sebagai alat untuk 
menggerakkan potensi yang ada dalam organisasi khususnya sumber daya manusia (SDM). Robbins (1996) dalam Eliana Hasan (2005:23) menyatakan bahwa dalam konteks organisasi, komunikasi mempunyai empat fungsi utama yaitu fungsi pengawasan, motivasi, pengungkapan emosional, dan informasi. Fungsi-fungsi komunikasi ini dapat berjalan dan dapat mendorong tercapainya tujuan baik individu maupun organisasi sangat tergantung pada kompetensi komunikasi individu maupun organisasi.

\section{Strategic Communication}

Sebuah organisasi akan berusaha untuk meningkatkan reputasinya melalui corporate advertising yaitu upaya mengkomunikasikan secara efektif dengan pegawai, untuk meyakinkan para stakeholders bahwa organisasi dalam kondisi sehat untuk berinvestasi, untuk menggiring konsumen supaya membeli produk organisasi. Untuk semua tujuan tersebut perlu memperhatikan communication strategy. (Argenti, 2012:28).

Upaya membangun komunikasi strategis sebuah organisasi harus memperhatikan kondisi organisasi. Efektivitas komunikasi strategic berhubungan dengan kondisi organisasi itu sendiri. Ada tiga hal yang digunakan untuk membangun strategic komunikasi yaitu :

1. Determining objectives

Yaitu mengacu pada perumusan tujuan komunikasi secara objektiv. Perumusan tujuan ini yang akan menjadi guide atau arah dari seluruh kegiatan komunikasi yang akan dilakukan. Disini harus dirumuskan apa yang diharapkan oleh organisasi dari konstituen/ sasaran komunikasi atas kegiatan komunikasi yang dilakukan. Suatu komunikasi dapat dikatakan berhasil apabila mendapatkan respon audien sesuai yang diharapkan. Untuk mendapatkan respon tersebut maka harus dipikirkan strategi komunikasi yang akan dilakukan.

2. Deciding what resources are available Setelah merumuskan apa yang akan dicapai, selanjutnya adalah menginventaris sumber daya/ kekuatan apa yang dimiliki organisasi yang dapat digunakan untuk menjalankan dan mensukseskan kegiatan komunikasi. Sumber daya yang dimaksud meliputi :

a. Uang

Komunikasi strategis dijalankan melalui serangkaian kegiatan atau program yang membutuhkan berbagai sarana dan media sehingga membutuhkan anggaran/ dana untuk membuat dan menjalankan berbagai kegiatan atau program tersebut. Tanpa adanya dukungan dana program tidak akan dapat terealisasi dengan baik.

b. SDM

SDM merupakan sumber daya yang mampu menggerakkan sumber daya-sumber daya lainnya. SDM yang akan merancang dan melaksanakan program komunikasi strategis dengan menggunakan sumber daya lainnya seperti dana, fasilitas, peralatan, media, dan lain sebagainya. Oleh karena itu diperlukan SDM yang memiliki kompetensi komunikasi. Kompetensi komunikasi terkait dengan kemampuan teknik komunikasi dan kemampuan kognitif yang dibangun dari kumpulan pengetahuan/ knowledge.

c. Waktu

Waktu menjadi sumber daya yang diperlukan dan harus diperhitungkan dalam menjalankan komunikasi strategis. Waktu terkait dengan kesempatan yang dimiliki oleh sebuah 
organisasi untuk menjalanan program-program komunikasi strategisnya. Sumber daya waktu sangat mempengaruhi model/ program komunikasi strategis yang akan dijalankan dan eektivitas pencapaiannya. Sehingga dalam setiap perencanaan kegiatan selalu disusun time schedule.

3. Analisa reputasi organisasi

Selain menginventaris sumber daya yang dimiliki sebagai sebuah kekuatan dan peluang untuk menyusun sebuah program komunikasi strategis, hal lain yang tidak kalah pentingnya adalah reputasi organisasi. Reputasi organisasi menjadi dasar bagi organisasi untuk menentukan tujuan apa yang akan dicapai dan kegiatan apa yang akan dilakukan. Karena pada dasarnya seluruh kegiatan ini diarahkan untuk mencapai reputasi organisasi yang baik di mata semua stakeholders. Dengan mengatahui sejauh mana reputasi organisasi maka dapat diketahui kekurangan dan kelebihan organisasi tersebut. Dengan demikian dapat dirancang program komunikasi strategis yang efektif.

\section{Definisi Konsep}

Strategic communication atau komunikasi strategis Arsip UGM adalah seluruh upaya yang dilakukan oleh Arsip UGM dalam rangka mencapai tujuannya dengan cara membangun reputasi positif serta menggerakkan seluruh stakeholder untuk berkontribusi positif terhadap eksistensi keberadaan Arsip UGM.

\section{Definisi Operasional}

Strategic communication Arsip UGM adalah kegiatan-kegiatan komunikasi yang dilakukan oleh Arsip UGM pada periode awal berdirinya Arsip UGM yaitu pada tahun 2004 - 2010. Komunikasi strategis ini akan dilihat dari perencanaan dan pelaksanaan program yang bertujuan untuk menjaga reputasi organisasi, menjaga kepercayaan stakeholder, dan mendapatkan dukungan dari stakeholder untuk kelangsungan hidup Arsip UGM. Perencanaan dan pelaksanaan tersebut terkait dengan perumusan tujuan, alokasi anggaran, alokasi sumber daya manusia, dan alokasi waktu.

\section{Metodologi Penelitian}

1. Objek Penelitian

Objek penelitian ini adalah arsip universitas/ arsip perguruan tinggi. Tahun 2009 melalui UU No. 43 Tahun 2009 tentang Kearsipan seluruh perguruan tinggi negeri diwajibkan membentuk arsip perguruan tinggi. Arsip UGM didirikan tahun 2004 sebelum terbitnya UU No. 43 Tahun 2009. Atas dasar tersebut penelitian ini mengambil sampel Arsip UGM sebagai objek penelitian karena memiliki kasus/ kondisi yang berbeda dengan arsip perguruan tinggi lainnya.

2. Metode Penelitian

Metode yang digunakan dalam penelitian ini adalah studi kasus, yaitu riset dengan menggunakan berbagai sumber data untuk meneliti, menguraikan, dan menjelaskan secara komprehensif berbagai aspek komunikasi dalam mengembangkan Arsip UGM sejak berdiri tahu 2004 sampai dengan tahun 2010 dalam mempertahankan eksestensinya.

3. Teknik Pengumpulan Data

Teknik pengumpulan data yang akan digunakan dalam penelitian ini meliputi :

a. Wawancara terhadap para pelaku sejarah pendirian dan pengembangan tahun pertama Arsip UGM.

b. Dokumentasi dilakukan dengan mengumpulkan dan menganalisa arsip-arsip terkait proses 
penelitian rencana pendirian Arsip UGM, peresmian Arsip UGM, serta arsip-arsip yang tercipta pada tahun pertama berdirinya Arsip UGM.

c. Analisis bukti-bukti fisik. Selain mengumpulkan dokumen/ arsip juga melihat bukti-bukti fisik atas peristiwa perintisan pendirian Arsip UGM serta pada tahun pertama berjalannya Arsip UGM.

4. Teknik Analisis Data

Teknik analisa data dalam penelitian ini dimulai dengan menganalisis berbagai data yang berhasil dikumpulkan melalui wawancara, dokumentasi arsip, dan observasi/ analisis bukti-bukti fisik yang menunjukkan proses perintisan pendirian Arsip UGM serta tahun pertama operasional Arsip UGM. Kemudian data-data tersebut didiklasifikasikan ke dalam kategorikategori tertentu sesuai dengan kebutuhan data penelitian. Setelah diklasifikasikan, dilakukan pemaknaan terhadap data tersebut untuk mendapatkan kesimpulan atau menjawab pertanyaan yang digunakan sebagai dasar penelitian ini.

\section{Limitasi Penelitian}

Penelitian ini merupakan penelitian pertama tentang komunikasi di lingkungan Arsip Perguruan Tinggi. Banyak penelitian komunikasi yang mengambil objek organisasi tetapi belum ada yang mengambil objek arsip perguruan tinggi dan Arsip UGM. Telah ada beberapa penelitian yang mengambil objek Arsip UGM tetapi topik penelitiannya bukan tentang komunikasi tetapi sebagian besar tentang kearsipan. Oleh karena itu penelitian ini menjadi penelitian awal tentang bentuk dan peran komunikasi dalam lembaga arsip perguruan tinggi khususnya Arsip UGM. Dengan demikian kemungkinan akan menemui banyak keterbatasan dalam mendapatkan sumber rujukan yang akan mengibatkan

penelitian ini.

\section{HASIL DAN PEMBAHASAN \\ Kondisi Arsip UGM Tahun 2004 - 2010}

Arsip UGM berdiri pada tanggal 11

September 2004 dan merupakan LKPT pertama di Indonesia. Periode sejak berdiri (2004) sampai dengan tahun 2010 skala prioritas Arsip UGM adalah penataan kelembagaan yang lebih tertuju pada infrastruktur seperti gedung, peralatan sarana dan prasarana kearsipan, SDM, dan aspek legalitas yang menjadi kebutuhan mendasar bagi tegaknya sebuah lembaga kearsipan. Setelah tahun 2010 Arsip UGM berorientasi pada pengembangan layanan arsip layanan internal dan eksternal (Effendhie, 2010). Arsip UGM sebagai LKPT pertama dan pilot project LKPT Indonesia mendorong Arsip UGM berupaya menjadi pusat rujukan pengembangan kearsipan perguruan tinggi di Indonesia. Berdasarkan UU 43 Tahun 2009 LKPT wajib melakukan pembinaan kearsipan dengan cara sosialisasi kearsipan kepada unit kerja dan sivitas akademika perguruan tinggi yang bersangkutan. Arsip UGM sebagai unsur penunjang universitas dituntut mampu menunjang penyelenggaraan tri dharma UGM dengan cara menyelamatkan memori kolektif UGM serta menyediakan arsip sebagai sumber informasi untuk kepentingan administrasi, pendidikan, dan penelitian. Orientasi publikasi kearsipan tahun 2004 - 2009 pada pimpinan dan pengelola arsip unit kerja UGM bukan sivitas akademika UGM. Pertimbangannya adalah mereka merupakan tulang punggung manajemen arsip unit kerja di UGM sebagai pembuat kebijakan dan pelaksana pengelolaan arsip unit kerja. Hal ini mengakibatkan publik sivitas akademika UGM kurang mengenal Arsip UGM. 


\section{Sasaran Komunikasi Strategis Arsip UGM 2004-2010}

Komunikasi strategis Arsip UGM dijalankan melalui berbagai cara dalam program publikasi kearsipan. Publikasi kearsipan di Indonesia menurut Hadiwardoyo (2002) merupakan kegiatan yang mengarah pada diseminasi informasi arsip, sedangkan menurut ANRI (2008) publikasi kearsipan tidak hanya diseminasi informasi arsip tetapi juga penyampaian informasi pengelolaan arsip atau "how to do it" dan perkembangan khazanah arsip. Publikasi kearsipan LKPT merupakan penyampaian informasi untuk layanan informasi mendukung administrasi perguruan tinggi, layanan informasi untuk penelitian dan pengembangan ilmu pengetahuan, serta sosialisasi sejarah perguruan tinggi (Maher, 1992). Publikasi kearsipan Arsip UGM tidak hanya berfungsi sebagai diseminasi arsip tetapi komunikasi korporat lembaga kearsipan. Publikasi kearsipan Arsip UGM dikembangkan beriringan dengan program kearsipan lainnya sejak Arsip UGM berdiri tahun 2004.

Publikasi kearsipan merupakan tahap akhir pengelolaan arsip jika hanya berfungsi sebagai diseminasi arsip, tetapi jika publikasi kearsipan berfungsi sebagai komunikasi korporat maka publikasi kearsipan dilakukan seiring dengan berdiri dan tumbuhnya lembaga tersebut. Strategi publikasi kearsipan berkembang dinamis mengikuti perkembangan Arsip UGM.

Program publikasi kearsipan Arsip UGM tahun 2004-2010 dilakukan dalam rangka mendukung tercapainya sasaran Arsip UGM saat itu. Tujuan Arsip UGM pada periode itu adalah penataan kelembagaan yang lebih tertuju pada infrastruktur seperti gedung, peralatan sarana dan prasarana kearsipan, SDM, dan aspek legalitas yang menjadi kebutuhan mendasar bagi tegaknya sebuah lembaga kearsipan. Pondasi itu dibangun untuk menuju visi Arsip UGM untuk menjadi pusat pengembangan dan layanan informasi kearsipan dalam menunjang universitas riset kelas dunia dan bertatakelola baik diantaranya dengan layanan kearsipan. Publikasi kearsipan Arsip UGM dilakukan untuk melaksanakan dan mengoptimalkan layanan internal dan eksternal informasi kearsipan. Tujuan publikasi kearsipan juga mengacu tujuan pembangunan kearsipan nasional dan tujuan UGM. Layanan yang dikembangkan meliputi layanan kearsipan komersial dan non komersial. Layanan komersial ditujukan kepada publik eksternal UGM. Publikasi kearsipan Arsip UGM berfungsi sebagai sarana layanan informasi, sarana untuk melakukan pembinaan kearsipan, dan sarana untuk pemasaran layanan khususnya layanan jasa kearsipan, dan sarana kehumasan Arsip UGM. Tugas tersebut menjadi tugas Bidang Layanan Arsip UGM yang menangani program publikasi kearsipan Arsip UGM.

\section{Strategi Publikasi Kearsipan Arsip UGM}

1. Kerangka Kerja Strategi Komunikasi Publikasi Kearsipan Arsip UGM 2004-2010

Kerangka kerja sebuah strategi komunikasi disusun berdasarkan tujuan dan sumber daya organisasi (SDM, dana, waktu, dan reputasi), serta kondisi audien (Argenti, 2009). Komunikasi tidak bisa lepas dengan konteks sosial atau lingkungan yang melingkupinya (West and Lynn H. Turner, 2014). Strategi publikasi kearsipan Arsip UGM dirancang untuk mencapai visi dan misi Arsip UGM dengan memperhatikan kondisi publik, kebijakan dan kearsipan nasional, lingkungan UGM, dan sumber daya Arsip UGM yang meliputi:

a. SDM kearsipan yang terdiri dari pejabat struktural, pejabat fungsional, dan administrasi umum yang kompeten di bidang kearsipan,

b. Alokasi dana publikasi kearsipan yang 
dianggarkan tiap tahun,

c. Informasi arsip dari khazanah arsip Arsip UGM dan informasi kearsipan, dan

d. Reputasi Arsip UGM sebagai lembaga kearsipan professional.

Strategi dirancang berdasarkan visi dan misi Arsip UGM dan disesuaikan dengan sumber daya yang dimiliki oleh Arsip UGM dan kondisi reputasi Arsip UGM. Arsip UGM menilai respon yang diberikan oleh publik serta menilai dampak dan manfaat yang diperoleh dari kegiatan publikasi tersebut. Arsip UGM melakukan evaluasi terhadap masingmasing kegiatan publikasi maupun evaluasi secara menyeluruh terhadap semua kegiatan publikasi kearsipan sebagai satu strategi yang utuh untuk mencapai visi dan misi Arsip UGM. Hasil evaluasi tersebut selanjutnya digunakan sebagai dasar dalam memperbaiki dan merancang kegiatan publikasi kearsipan selanjutnya.

\section{Strategi Komunikasi Publikasi Kearsipan Arsip UGM 2004-2010}

Menurut Argenti (2009) strategi komunikasi disusun berdasarkan tujuan yang hendak dicapai organisasi. Strategi komunikasi untuk menciptakan komitmen publik menurut Joep Cornelissen dalam Asdhianti (2015) dapat dirancang dan dilaksanakan berdasarkan efek yang diharapkan terhadap audien selaku pemangku kepentingan organisasi. Komunikasi untuk menciptakan kesadaran biasanya menggunakan strategi informasional, untuk menciptakan pemahaman menggunakan strategi persuasif atau informasional, untuk menciptakan keterlibatan menggunakan strategi dialog, dan untuk menciptakan komitmen menggunakan strategi dialog.

Strategi yang digunakan oleh Arsip UGM dalam melakukan publikasi kearsipan adalah :

a. Edukasi kearsipan: sebagai bentuk dari fungsi pembinaan kearsipan dan pengabdian perguruan tinggi. Tema/ pesan yang disampaikan adalah pengetahuan dan pemahaman kearsipan tentang "why" atau pentingnya/peran arsip dan "how" bagaimana cara pengelolaan arsip. Strategi ini dilakukan melalui seminar, lomba karya tulis, artikel dan peraturan kearsipan di website Arsip UGM dan Buletin Khazanah untuk berbagi ilmu dan pengalaman kearsipan kepada masyarakat.

b. Sosialisi lembaga Arsip UGM: untuk mengenalkan Arsip UGM kepada sivitas akademika dan publik karena Arsip UGM merupakan unit kerja baru di lingkungan UGM dan sebagai konsep baru lembaga kearsipan di Indonesia.

c. Desimenasi isi informasi arsip: menyediakan isi informasi arsip melalui naskah sumber arsip dan pameran arsip sebagai sarana temu kembali dan mengenalkan khazanah arsip Arsip UGM.

d. Promosi khazanah arsip: menyampaikan jenis-jenis arsip dan cara akses arsip kepada publik internal UGM dan eksternal UGM untuk meningkatkan layanan arsip. Strategi ini disampaikan melalui poster yang dibuat secara tematis bersumber pada khazanah arsip yang dimiliki oleh Arsip UGM.

e. Membangun reputasi Arsip UGM: menampilkan berita-berita positif untuk membangun reputasi arsip UGM melalui media publikasi cetak yang diterbitkan oleh Arsip UGM yaitu News Letter yang kemudian berubah menjadi Buletin Khazanah. Membangun reputasi ini dilakukan dengan membuat artikel terkait berbagai kegiatan Arsip UGM pada kolom berita dan cover dalam belakang, serta kolom berita website Arsip UGM dengan menampilkan berita dan foto kegiatan bernilai positif dan prestasi Arsip UGM.

f. Membangun Citra UGM: menyajikan 
informasi sejarah, prestasi, dan tri dharma UGM untuk membangun citra UGM melalui kegiatan pameran arsip, naskah sumber arsip, film dokumenter, dan Kolom Telisik Buletin Khazanah.

\section{Taktik Publikasi Kearsipan Arsip UGM}

Strategi publikasi kearsipan Arsip UGM diwujudkan melalui berbagai taktik yaitu metode atau kegiatan yang digunakan untuk menerapkan strategi (Gregory, 2010). Taktik disusun dalam Rencana Kerja dan Anggaran Tahunan (RKAT) Arsip UGM. Taktik publikasi kearsipan Arsip UGM adalah pameran arsip konvensional dan virtual, buletin kearsipan secara cetak dan online, naskah sumber arsip cetak, film dokumenter, leaflet khazanah arsip, profil lembaga dalam bentuk cetak dan audiovisual, seminar kearsipan, dan website. Taktik tersebut meliputi komponen:

a. Audien: seluruh stakeholder Arsip UGM yang dapat dikelompokkan berdasarkan ikatan organisasi dan kepentingannya. Audien tersebut meliputi audien internal UGM yang terdiri dari unit kerja UGM (Pimpinan unit kerja dan pengelola arsip unit kerja UGM) dan sivitas akademika UGM (dosen, mahasiswa, dan pegawai UGM); dan audien eksternal UGM yang terdiri dari komunitas kearsipan (perguruan tinggi dan organisasi kearsipan non perguruan tinggi) dan masyarakat umum.

b. Pesan: pesan yang disampaikan dalam publikasi kearsipan merupakan implementasi dari strategi publikasi kearsipan yang telah ditetapkan, terdiri dari:

1) Pesan untuk edukasi kearsipan Informasi berupa artikel-artikel kearsipan tentang pengetahuan dan keterampilan kearsipan seperti peran arsip perguruan tinggi; peranan arsip dalam berbagai bidang seperti pendidikan, demokrasi, pengembangan ilmu pengetahuan, dan ekonomi kreatif; dan artikel tentang manajemen kearsipan seperti penataan arsip kacau, pengelolaan arsip foto, dan preservasi arsip. Pesan-pesan disampaikan melalui Buletin Khazanah, buku kearsipan, seminar, diskusi, workshop, dan bimtek.

2) Pesan untuk mensosialisasikan

Pesan sosialisasi Arsip UGM dilakukan dengan cara mencantumkan identitas Arsip UGM dalam setiap produk publikasi kearsipan Arsip UGM. Dalam setiap pameran arsip, setiap foto yang dipamerkan dibelakang keterangan peristiwa foto diberi tulisan "KHAZANAH ARSIP UGM", dipasang banner tentang Arsip UGM dan dibagikan leaflet profil Arsip UGM.

3) Pesan untuk mendesimenasikan Pesan yang disampaikan kepada publik untuk mendesimenasikan informasi isi arsip adalah informasi tentang suatu peristiwa, sejarah suatu organisasi, atau suatu tema tertentu yang diulas berdasarkarkan informasi dari arsip seperti sejarah peristiwa atau lembaga di lingkungan UGM.

4) Pesan untuk mempromosikan

Pesan mempromosikan khazanah arsip dilakukan dengan menyajikan fisik khazanah arsip baik secara langsung (fisiknya) maupun dengan soft 6 ile. Arsip yang ditampilkan memiliki nilai ekstrinsik yaitu nilai informasi yang tertuang dalam arsip tersebut, dan atau memiliki nilai intrinsik yaitu nilai keunikan yang terdapat dalam media rekam arsip seperti bentuk kertas maupun bentuk huruf yang unik. Nilai ekstrinsik misalnya arsip tentang budaya nusantara, tentang 
pancasila, tentang penelitianpenelitian penting. Nilai intrinsik misalnya surat UGM tahun 1949 yang jenis dan ukuran kertasnya unik atau bentuk stempelnya. Promosi ini juga menyampaikan jenis khazanah arsip Arsip UGM dan cara aksesnya.

5) Pesan untuk membangun reputasi Pesan-pesan untuk membangun reputasi Arsip UGM ini berupa berita-berita tentang prestasi lembaga dan prestasi perseorangan arsiparis Arsip UGM, serta kegiatan-kegiatan di Arsip UGM yang dianggap dapat menunjukkan Arsip UGM sebagai LKPT yang professional seperti kunjungan dari instansi-instansi besar, pengelolaan arsip yang memiliki nilai strategis, serta program kearsipan unggulan seperti menerima kunjungan pejabat, prestasi lembaga, seminar, pameran, dan sebagainya.

6) Pesan untuk membangun reputasi

Pesan untuk membangun reputasi UGM dikemas dengan informasi prestasi dan sejarah UGM di masa lalu serta jati diri UGM sebagai universitas pancasila, universitas kebudayaan, universitas kerakyatan yang dapat dilihat dari bukti-bukti arsip. Pameran arsip yang diselenggarakan oleh Arsip UGM menyajikan informasiinformasi tentang hal-hal positif terkait UGM yang dapat memperkuat reputasi UGM.

c. Saluran: saluran yang digunakan dalam publikasi kearsipan disesuaikan dengan jenis pesan yang akan disampaikan, kondisi geografis publik, serta kemampuan Arsip UGM. Saluran yang digunakan dalam publikasi kearsipan Arsip UGM adalah:

1) Media Lini Bawah/Korporasi/ Controlled Media:

a) Media cetak: untuk menyampaikan informasi yang bersifat penting, rinci, dan memiliki tingkat kesulitan tinggi seperti informasi tentang pentingnya arsip, teknik pengelolaan arsip, informasi rinci Arsip UGM, dan isi informasi arsip. Pertimbangan lainnya adalah publik sasaran tersebar di seluruh wilayah Indonesia sulit dijangkau secara langsung serta kemampuan penguasaan teknologi masih kurang. Media cetak meliputi: Buletin Khazanah, naskah sumber arsip, leaflet informasi khazanah arsip dan akses arsip, buku dan leaflet profil Arsip UGM, dan banner.

b) Media online: untuk mengikuti perkembangan TIK dan pertimbangan efisiensi biaya serta efektivitas capaian jangkauan audien, Arsip UGM melakukan inovasi dengan memanfaatkan media berbasis internet yaitu website.

c) Tatap muka/langsung: untuk menyampaikan promosi khazanah arsip dengan menampilkan fisik arsip baik foto, tekstual, maupun kaset; serta informasi tentang pentingnya arsip dan cara pengelolaan arsip. Saluran tatap muka/langsung ini meliputi diskusi, seminar, bimtek, dan pameran arsip. Keuntungan dari saluran ini adalah dapat bertemu dan berdialog langsung dengan audien, dapat memberikan penjelasan secara rinci, dan mendapatkan feedback secara langsung.

2) Media Lini Atas /Media Massa/ Uncontrolled Media

Saluran publikasi melalui media massa, media korporasi yang 
dikelola oleh UGM, serta media yang dikelola oleh lembaga atau orang di luar UGM sebagai publisitas yang diperoleh Arsip UGM.

d. Feedback/ Respon Audien: meliputi feedback yang menimbulkan efek terprediksi dan tidak diprediksi. Feedback terprediksi meliputi terselenggaranya layanan arsip dan kearsipan, tercapainya publisitas tentang arsip dan Arsip UGM, dan terbangunnya reputasi Arsip UGM. Feedback tidak diprediksi meliputi dukungan materi, donatur arsip, dan dukungan terhadap pelaksanaan program kearsipan lainnya. Feedback ini juga berdampak positif pada pembangunan kearsipan nasional, pencapaian tujuan UGM, serta terselengaranya misi Arsip UGM untuk terwujudnya visi Arsip UGM.

e. Evaluasi: evaluasi dilakukan dengan menjaring kritik dan saran audien dan rapat evaluasi kegiatan.

\section{Efektivitas Publikasi Kearsipan Arsip UGM}

Efektifitas komunikasi menurut Ruben (2014) dipengaruhi oleh audien, pesan, sumber, dan teknologi dan lingkungan. Gregory (2004) menyebutkan faktor yang diperhatikan dalam melakukan analisis publik/audien adalah jangkauan, jumlah dan lokasi, pengaruh dan kekuasaan, serta hubungan dengan organisasi. Arsip UGM belum melakukan segmentasi publik. Kegiatan publikasi kearsipan berlaku umum untuk semua sasaran sehingga mempengaruhi efektifitas publikasi yang dilakukan. Taktik publikasi kearsipan Arsip UGM sejak tahun 2004 telah menggunakan teknologi internet seperti Galeri Foto sejak 2010, dan Galeri Film sejak 2010. Penggunaan teknologi internet ini juga membantu perluasan jangkauan sasaran serta penghematan biaya publikasi.

Strategi pesan meliputi dua aspek yaitu isi pesan mengacu pada tujuan dan strategi komunikasi dapat disusun dengan pendekatan persuasif, informatif, instruktif, dan hiburan; dan format pesan dengan menyesuaikan saluran yang akan digunakan (Ruben, 2014). Pesan publikasi kearsipan dapat digunakan sebagai media berdialog dengan publik dengan menangkap isu-isu yang sedang berkembang di masyarakat sebagai tema atau materi publikasi. Keberhasilan komunikasi menurut Ferquson (1999) dapat dilihat dari feedback audien berdasarkan tingkat pengetahuan yang ditunjukkan publik, jumlah anggota baru yang memberikan dukungan materi pada organisasi, dan jumlah anggota yang berpartisipasi dalam kegiatan. Publik yang terkena terpaan pesan publikasi kearsipan Arsip UGM rata-rata memberikan respon positif. Berdasarkan hasil wawancara terhadap audien yaitu mahasiswa UGM, peneliti UGM, pegawai UGM, dan publik eksternal UGM menunjukkan bahwa mereka mengenal arsip dan Arsip UGM setelah mendapatkan informasi dari publikasi kearsipan Arsip UGM seperti pameran, buletin, website, dan publisitas/ pemberitaan di media massa. Setelah mendapatkan informasi tersebut mereka kemudian menggunakan layanan kearsipan Arsip UGM.

Feedback publikasi kearsipan berdampak positif pada: peningkatan layanan internal dan eksternal Arsip UGM; publisitas; mendukung penyelenggaraan kearsipan seperti mendapatkan dukungan materi dan non materi dari pimpinan unit kerja UGM dan publik eksternal UGM, mendapatkan donor arsip, meningkatkan pengetahuan, kesadaran, dan keterampilan dalam pengelolaan dan penyelamatan arsip di UGM. Publikasi kearsipan berperan dalam pelaksanaan tri dharma UGM, menanamkan nilai-nilai ke-UGM-an, dan membangun citra UGM. Publikasi kearsipan Arsip UGM berdampak pada pembangunan kearsipan nasional dengan 
turut membangun kesadaran, pengetahuan, dan keterampilan kearsipan, mendorong implementasi UU No. 43 tahun 2009 khususnya pengembangan LKPT di Indonesia.

\section{KESIMPULAN}

Komunikasi strategis Arsip UGM sejak Arsip UGM berdiri tahun 2004 hingga tahun 2010 dilakukan melalui berbagai kegiatan dalam program publikasi kearsipan. Program publikasi kearsipan dikembangkan di bawah koordinasi Bidang Layanan Arsip UGM. Publikasi kearsipan Arsip UGM tahun 2004-2010 untuk skala prioritas tujuan Arsip UGM yaitu penataan kelembagaan yang lebih tertuju pada infrastruktur seperti gedung, peralatan sarana dan prasarana kearsipan, SDM, dan aspek legalitas yang menjadi kebutuhan mendasar bagi tegaknya sebuah lembaga kearsipan. Setelah tahun 2010 Arsip UGM berorientasi pada pengembangan layanan arsip layanan internal dan eksternal. Oleh karena itu kegiatan publikasi kearsipan dikembangkan secara sistematis untuk mendapatkan dukungan dari berbagai stakeholder khususnya dari pimpinan UGM dan seluruh unit kerja di lingkungan UGM. Dukungan ini sangat diperlukan untuk mempertahankan eksistensi Arsip UGM dan untuk mendapatkan dukungan material maupun non material dalam rangka pemenuhan berbagai kebutuhan Arsip UGM sebagai sebuah unit kerja baru di lingkungan UGM dan sekaligus sebagai lembaga kearsipan perguruan tinggi pertama di Indonesia.

Strategi publikasi kearsipan Arsip UGM adalah edukasi kearsipan, sosialisi Arsip UGM, diseminasi isi informasi arsip, promosi khazanah arsip, membangun reputasi Arsip UGM, dan membangun Citra UGM. Taktik yang digunakan adalah pameran arsip konvensional dan virtual, buletin kearsipan secara cetak dan online, naskah sumber arsip, film dokumenter, leaflet khazanah arsip, profil lembaga dalam bentuk cetak dan audiovisual, seminar kearsipan, website. Media yang digunakan berbasis pada media publikasi yang dikelola oleh Arsip UGM dan media yang dikelola oleh pihak lain yang terdiri dari media massa baik cetak maupun online, media online organisasi lain (website) dan media yang dikelola oleh UGM.

Perlu dilakukan penelitian publikasi kearsipan Arsip UGM dari sisi audien untuk mengetahui tingkat keberhasilan program sekaligus dapat memperoleh gambaran strategi publikasi kearsipan secara utuh dari sisi komunikator dan komunikan/audien. Arsip UGM dapat lebih aktif dan inovatif dalam mengembangkan program publikasi kearsipan sesuai dengan kebutuhan dan kondisi. Penelitian tentang publikasi kearsipan dapat dilakukan dengan menggunakan pendekatan teori atau konsep komunikasi pembangunan, komunikasi pemasaran, dan komunikasi korporat/PR untuk mengetahui fungsifungsi komunikasi dalam publikasi kearsipan. Pakar dan ilmuwan komunikasi dapat berperan menyumbangkan ilmu komunikasi untuk pengembangan program-program kearsipan dari aspek komunikasi. Perlu dilakukan penelitian publikasi kearsipan di lembaga kearsipan tingkat nasional, propinsi, dan kabupaten/kota untuk memperoleh gambaran model publikasi kearsipan di Indonesia secara menyeluruh dan mengkaji model publikasi kearsipan di Indonesia.

\section{DAFTAR PUSTAKA}

Abdullah Masmumah, 2008, Komunikasi Organisasi dalam Perspektif Teori dan Praktek, Malang: UMM Press.

ANRI (2011), Kajian SDM Kearispan/ Arsiparis di Lembaga Kearsipan Kabupaten/Kota, Jakarta: ANRI 
ANRI, (2008). Manajemen Layanan Informasi. Jakarta: ANRI

ANRI. (tt). Publikasi Kearsipan. Jakarta: ANRI.

Anwar Arifin, 1984, Strategi Komunikasi Sebuah Pengantar Ringkas, Bandung: Penebit Armico.

Argenti, Paul A.. (2009). Corporate Communication. North America: McGraw-Hill Education.

Astrid S. Susanto. 1977. Komunikasi Kontemporer. Jakarta: Penerbit Binacipta.

Baird, John E. (1977). The Dinamics of Organizational Communication. London: Harper \& Row Publishers.

Benoit, William L. \& Pamela J. Benoit. ((2008). Persuasive Messages: The Process of Influence. Australia: Blackwell Publishing.

Berger, Charles R., Michael E. Roloff, David R. Roskos-Ewoldsen. (2015). Handbook Ilmu Komunikasi. Diterjemahkan oleh Derta Sri Widowatie, Cetakan ke III. Bandung: Nusa Media.

Brown, John Seely and Paul Duguid. (2000). The Social Life of Information. USA: Harvard College.

Cutlip and Center's. (2013). Effective Public Relations. $11^{\text {th }}$ Edition. England: Pearson Education Limited.

Effendhie, Machmoed. (2010). Panduan Akses dan Layanan Arsip. Yogyakarta: Arsip UGM.

Effendy, Onong Uchjana. (2003). Ilmu Komunikasi: Teori dan Praktek. Bandung: PT. Remaja Rosdakarya
Erliana Hasan, 2005. Komunikasi Pemerintahan. Bandung: PT. Re $\mathrm{P}$ ka Aditama.

Ferguson, Sherry Devereaux. (1999). Communication Planning an Integrated Approach, California: Sage Publication, Inc.

Gregory, Anne. ( 2004). Alih bahasa Dewi Damayanti . Seri Praktik PR: Perencanaan dan Manajemen Kampanye Public Relations. Edisi kedua. Jakarta: Penerbit Erlangga.

Gregory, Anne. (2010). Planning and Managing Public Relations Campaigns: A Strategic Approach. London: Kogan Page

Griffin Em. 2012. A First Look at Communication Theory. New York : McGraw-Hill Education.

Hadiwardoyo, Sauki. (2002). Terminologi Kearsipan Nasional, Jakarta: ANRI.

Hallahan, Kirk., Derina Holtzhausen, Betteke van Ruler, Dejan Vercic, and Krishnamurthy Sriramesh. (2007). Defining Strategic Communication. International Journal of Strategic Communication, I (5), 644 ${ }^{1}$. pp 7-35.

Hasan, Erliana. (2005). Komunikasi Pemerintahan. Bandung: PT. Re ${ }^{\mathrm{P}} \mathrm{ka}$ Aditama.

Hirsch, Herbert L. (2003) Essential Communication Strategies: for Scientists, Engineers and Technology Professionals. Second Edition, Canada: John Wiley \& Son. Inc.

Jablin, Frederic M., \& Linda L Putman (Ed), 2001. The New Handbook of Organizational Communication: Advances in Theory, Research, and Methods. London: Sage Publication 
Inc.

Kriyantono, Rachmat. (2008). Public

Relations Writing: Teknik Produksi

Media Public Relations dan Publisitas

Korporat. Cetakan kedua. Jakarta:

Kencana Prenada Media Group.

Kriyantono, Rachmat. (2012). Teknik Praktis Riset Komunikasi. Jakarta: Kencana Prenada Media Group.

Laksmi, Tamara Adriani Sosetyo-Salim, Ari Imansyah. (2011). Manajemen Lembaga Infomormasi: Teori dan Praktik. Jakarta: Penaku.

Ludlou, Ron \& Panton. (1992). Effective Communication, UK: Prentice Hall International.

Maher, William J. (1992). The Management of College and University Archives. Amerika: Metucgen N.J. The Society American Archivist and The Scarecrow Press, Inc.

Pace, R. Wayne \& Don F. Faules. (2013). Komunikasi Organisasi: Strategi Meningkatkan Kinerja Perusahaan. Diterjemahkan oleh Deddy Mulyana, Bandung: PT. Remaja Rosdakarya.

Rosmawaty, 2010. Mengenal Ilmu Komunikasi. Jakarta: Widya Padjajaran.

Ruben, Brent D. and Lea P. Stewart. (2014). Komunikasi dan Perilaku Komunikasi. Jakarta: PT. RajaGrafindo Persada.

Ruslan, Rosady. (1999). Manajemen Humas dan Manajemen Komunikasi. Jakarta: PT. RajaGrafindo Persada.

Society of American Archivist, (1999). Guidelines for College and University Archives. Amerika: SAA.
Steers, Richard M. (1980). Efektivitas Organisasi. Jakarta: Erlanggga.

Sugihartati, Rahma. (2014).

Perkembangan Masyarakat

Informasi \& Teori Sosial

Kontemporer, Jakarta: Kencana

Prenadamedia Group

Sunyoto, Bonifatius Tulus. (2015). "Strategi komunikasi Pusat Informasi dan Konseling Remaja Kabupaten Sleman untuk Mewujudkan Remaja Bebas Resiko "TRIAD KRR"'”. Tesis pada S2 Penyuluhan dan Komunikasi Pembangunan UGM: tidak diterbitkan.

West, Richard and Lynn H. Turner (2014). Pengantar Teori Komunikasi: Analisis dan Aplikasi. Jakarta: Penerbit Salemba Humanika.

Widyarsono, Toto. (2009). Publikasi dan Pameran Arsip. Jakarta: Universitas Terbuka

\section{Peraturan Perundang-Undangan}

Undang-Undang RI Nomor 14 Tahun 2008 tentang Keterbukaan Informasi Publik

Undang-Undang RI Nomor 43 Tahun 2009 tentang Kearsipan

Peraturan Pemerintah RI No. 48 Tahun 2012 tentang Pelaksanaan UndangUndang RI Nomor 43 Tahun 2009 tentang Kearsipan

Keputusan Presiden RI No. 105 Tahun 2004 tentang Pengelolaan Arsip Statis 
Surat Keputusan Majelis Wali Amanat UGM Nomor 29/SK /MWA /2007 tentang Rencana Strategis Universitas Gadjah Mada Tahun $2008-2012$ 